\title{
International Legal Protection of Linguistic Minorities with the Example of the French Republic
}

\author{
Aslan Khuseinovich Abashidze \\ Department of International Law, RUDN University, \\ Moscow, Russia \\ abashidze_akh@pfur.ru
}

\author{
Aleksandra Evgen'evna Koneva \\ Department of International Law, RUDN University, \\ Moscow, Russia \\ koneva_ae@pfur.ru
}

\author{
Alexander Mikhailovich Solntsev \\ Department of International Law, RUDN University, \\ Moscow, Russia \\ a.solntsew@gmail.com
}

\author{
Aleksandra Sergeevna Babanskaya \\ Moscow, Russia \\ alexandra.babanskaya@yandex.ru
}

Denis Andreevich Gugunskiy

Department of International Law, RUDN University

Moscow, Russia

gugunskiy_da@pfur.ru

\begin{abstract}
In many states, minorities irrespective of whether they are national or ethnic, religious or linguistic have been always representing one of the most vulnerable groups of people. This paper gives the definition of the term "minority", and analyses international legal framework for the protection of minority rights and realization of the international legal standards on linguistic minorities rights protection in the French Republic.
\end{abstract}

Keywords-Human rights; Minorities; Linguistic; France

\section{INTRODUCTION}

In all countries of the world minorities irrespective of whether they are national or ethnic, religious or linguistic were and still represent one of the most vulnerable groups of people. For the first time the international community drew its attention to the problem of minority protection in the middle of the XVI century. However, the first international system of the minority rights protection was established only in the XX century under the auspices of the League of Nations through the adoption of several special agreements concluded with the countries of Eastern and Central Europe. But the whole minority treaties system soon proved to be ineffective and failed, as did eventually the Leagues of Nations itself.

\section{DEFINITION OF THE TERM “MINORITY".}

Various UN bodies, academics as well as organizations have made attempts to formulate a definition of a "minority". It has been often highlighted that the existence of a minority is a question of fact, but not of States' decision on whether or not to recognize this group of population within their territories [1]. Further, it is commonly accepted that the definition of the term "minority" should reflect both objective and subjective factors/criteria. The objective criteria encompass the shared characteristics of the group such as ethnicity, national origin, culture, language or religion, while the subjective criteria address the principle of self-identification and the desire to preserve the group's identity. The main shortcoming of the most well-known definitions of a "minority" that have been proposed at different times was the inclusion of the nationality criterion. In fact, minorities don't have to be citizens in order to claim basic minority rights, but historically resident minorities may have claims to greater positive measures than those minorities who have more recently arrived.

No international legal instrument, which is concerned with the minority rights protection, defines either a minority per se or any category of minorities.

In the absence of a definition that would satisfy the interests of all members of the world community, each State develops its own definition of minorities on the basis of its political considerations, but with due regard to the international legal requirements.

As for the concept of a "linguistic minority", it represents the sphere of interest of both linguistics and law, which, unfortunately, haven't sufficiently interacted in the past, and that has undeniably led to negative consequences. In the international legal sphere, as a result of the complexity of the phenomena of "minorities", the situation regarding the definition of the term "linguistic minority" is exactly similar to the one of the term "minority" to the extent that there exists no generally recognized legal definition of this expression and that any international human rights standard for protecting minority rights contains no suggestion on this issue [2].

We adhere to the definition of a "minority" which states that it is "a national, ethnic, religious or linguistic group that differs from the other groups within the territory of the sovereign State" [3]. We believe that, by analogy to this 
definition, a "linguistic minority" may be defined in general terms as a linguistic group that differs from the other groups within the territory of the sovereign State.

\section{INTERNATIONAL LEGAL FRAMEWORK FOR THE PROTECTION OF MINORITY RIGHTS}

The whole range of internationally recognized human rights standards and principles protect the rights of linguistic minorities and of minorities in general since human rights are universal by definition. For linguistic minorities, language is a central element and expression of their identity and of key importance in the preservation of their distinct group and cultural identity, sometimes under conditions of marginalization, exclusion and discrimination. For this reason, language rights and linguistic human rights, from which the first ones are usually considered broader, are of particular importance for linguistic minorities. Various human rights and freedoms provisions cover language rights, such as the prohibition of discrimination, freedom of expression, the right to private life, the right to education, and the right of linguistic minorities to use their own language with others in their group.

The specific linguistic minority provisions can be found in articles 2(1), 19(2), 27 of the 1966 International Covenant on Civil and Political Rights (ICCPR), article 2 (2) of the 1966 International Covenant on Economic, Social and Cultural Rights (ICESCR), article 30 of the 1989 Convention on the Rights of the Child (CRC). The 1992 United Nations Declaration on the Rights of Persons Belonging to National or Ethnic, Religious and Linguistic Minorities (UNDM) further elaborates the rights of minorities, including regarding language. Articles 1, 2 (1), 4(2-3) of the Declaration can be regarded as those containing particularly important provisions. Article 27 of the International Covenant on Civil and Political Rights and article 30 of the Convention on the Rights of the Child contain the most widely accepted binding provisions on minorities, while the UNDM, notwithstanding its non-binding nature, is the first document that dealt solely with minority rights' issues and that fixed the main international norms and standards on the enforcement of minority rights.

Within the framework of the Council of Europe (CoE), the rights of linguistic minorities are well protected mainly by the 1992 European Charter for Regional or Minority Languages (ECRML) and the 1995 Framework Convention for the Protection of National Minorities (FCNM). The Charter provides principles and objectives upon which States parties must base their policies, legislation and practice relating to regional or minority languages as well as a series of specific measures relating to diverse areas relevant to minority language use. The Convention has extensive provisions for the protection of the linguistic minority rights and minority languages in articles 5, 9-14. Although the 1950 Convention for the Protection of Human Rights and Fundamental Freedoms (ECHR) does not include provisions on the protection of rights of minorities, the European Court of Human Rights in its jurisprudence dealt with these questions, especially protected the rights of linguistic minorities' members and foreign citizens, through application of different rights protected by the Convention [4]. In particular, linguistic rights were be protected under articles 8-10, 14 of the
Convention, article 2 of its Protocol No.1 and article 1 of Protocol No.12.

\section{REALIZATION OF THE INTERNATIONAL LEGAL} STANDARDS ON LINGUISTIC MINORITIES RIGHTS PROTECTION IN THE FRENCH REPUBLIC

As for French linguistic minorities, they aren't recognized in France since the mere existence of minorities per se within its territory is denied by the State, which is a semi presidential Republic with the population of more than 66 million people, since their recognition would encroach on the constitutional principles of the indivisibility of the Republic, equality before the law and the unity of the French people. However, the French linguistic diversity is quite huge and comprises from 10 to 23 languages identified as the regional languages (Romanic and Non-Romanic) spoken within the territory of metropolitan France, depending on the fact whether the dialects of the groups Langue d'oc and Langue d'oïl are treated as independent units of a higher order. According to the latest official available data, in 1999 the French regional languages were spoken by approximately 4, $2-10 \%$ of the French.

Throughout its centuries-long history France showed great consideration for the language related issues. Since the XVI century the centralized language policy was mainly focused on the widespread dissemination and adoption of the common official standardized language, that is French, and on the extrusion of all the other forms of language. The apogee of the fight against the local idioms encompasses the period dating from the end of the XVIII century, when France made the destruction of dialects and patois its official policy, till the XIX century inclusive, when the policy of the so-called "cultural genocide" in relation to these forms of language was approved. The re-examination of the main principles of the language policy and law began only in the second half of XX century, when various drafts designed for the protection of the regional languages were prepared in France, though subsequently only few of those were adopted. As a result, nowadays the languages of the French linguistic minorities may be officially, albeit to a limited extent, used in education and in media. In other fields these languages can be used in place of or along with French with rare exception.

The French Republic's tradition of commitment to human rights can be traced to the eighteenth century. It was enshrined in the Declaration of the Rights of Man and of Citizens of 1789, which is referred to in the preamble to the French Constitution of 4 October 1958 in force, and has the value of a constitutional norm. This commitment has more recently been enriched by accession of France to many international treaties. In particular, it became a State party to all core international human rights instruments, with the exception of the International Convention on the Protection of the Rights of All Migrant Workers and Members of Their Families. The current system for the protection of human rights is closely linked to the legal and political framework of France. In addition, the State actively supports and appreciates the activities of the Office of the High Commissioner for Human Rights (OHCHR). It has also contributed to the task of strengthening the Human Rights Council, to the creation of new Council's Special Procedures, to which it issued a standing invitation, and to the preparation 
of UN GA country-specific and thematic resolutions. Moreover France is one of the first States that underwent the first cycle of Universal Periodic Review (UPR) and one of the first Signatory States to the ECHR. It is also a founder member of the $\mathrm{CoE}$ and a State party to a number of its legal human rights instruments.

Although France is a State party to all universal legally binding instruments concerned with the minority rights protection, in general only their minority-specific antidiscrimination provisions apply to French minorities, because France made reservations to the article 27 of the ICCPR and article 30 of the CRC. As regards the relevant main legal instruments of CoE, France is a State party only to the ECHR, but at the same time it neither signed nor ratified Protocol No. 12 providing for a general prohibition of discrimination. Moreover, France signed the ECRML as far back as in 1999, but still hasn't ratified it.

It further follows that the specific-minority provisions relevant for linguistic minorities of only articles 2(1), 19(2) of the ICCPR and article 2 (2) of ICESCR apply to French linguistic minorities. Linguistic rights of French linguistic minorities may be protected under articles 8-10, 14 of the ECHR and article 2 of its Protocol No.1.

It appears so that only three human rights treaty bodies [5], namely the Committee on Economic, Social and Cultural Rights (CESCR), the Human Rights Committee (HRC), and the Committee on the Rights of the Child (CRC), which are accountable for monitoring the implementation of the respective core international human rights treaties, covered in detail matters linked to the situation and fate of minorities in general and specifically of linguistic ones in France and made subsequent recommendations in their concluding observations on the periodic reports of the State party.

We may conclude from the examined periodic reports of France to the above-mentioned treaty bodies [6] that it has taken a number of positive steps in order to maintain and promote regional and minority languages and cultures, in particular measures in the fields of education, media and culture. However, the Committee on Economic, Social and Cultural Rights found that these measures didn't constitute sufficient efforts on the part of the State. Further, it follows that any changes in the situation and legal status of minorities can hardly be expected since France is entirely devoted to the French concept and doesn't plan to renounce its constitutional considerations in the nearest future or to adopt any amendment to the Constitution in order to cope with the minority problem, as it has been multiple times highlighted by the State party in its periodic reports to the above mentioned committees. France also confirmed multiple times that it still didn't plan to withdraw its reservations to article 27 of the ICCPR and article 30 of the CRC, as well as to ratify the FCNM or the ECRML due to its constitutional considerations.

Further, it turns out that only the CCPR and CRC revealed some positive developments with regard to minority issues in the periodic reports of France, in particular the measures taken by the State party to preserve and promote its national cultural and linguistic diversity. However, the number of grounds for anxiety undeniably prevailed in their concluding observations.
As for common issues of concern, CCPR, CESCR, and CRC were unanimous that France should review its position with regard to the formal recognition of minorities within its territory. This recommendation of the treaty bodies is very important, since it addresses the problem that has become immensely burning in France in recent years and covers minorities in general, notwithstanding whether they are national/ethnic, religious or linguistic. Another serious problem brought up by the treaty bodies was the reluctance of France to withdraw its interpretative declaration to article 27 of the ICCPR and its reservation to article 30 of the CRC, the provisions of which are of high significance for the protection of minorities' rights. The issues that are vital specifically for linguistic minorities were mainly brought up by CESCR, which formulated a sufficient number of relevant recommendations on such issues as non acceptance of international norms, the lack of formal recognition of regional and minority languages, preservation of linguistic and cultural diversity, etc.

The analysis of the 2007 report of the UN Special Rapporteur on minority issues on visit to France [7] has revealed some inaccuracies and omissions, which, as we believe, took place because the madate-holder paid more attention to the information obtained during the questionnaire survey conducted among representatives of some French linguistic minorities rather than to the data from official sources. Notwithstanding this circumstance, the importance and significance of the report prepared by Ms. G. McDougall are beyond doubt.

We may conclude on the basis of this report that French linguistic minorities continued to experience diverse challenges and that Special Rapporteur on minority issues shared the same concerns with the CCPR, CESCR, and CRC, namely: the nonrecognition of minorities by France, non-withdrawing of its reservations to article 27 of the ICCPR and article 30 of CRC, non ratification of the human rights treaties of $\mathrm{CoE}$ that relate to minority rights (in particular, the ECRML, the FCNM, Protocol No.12 to the ECHR). The SR also called upon France to support the use of regional and minority languages, specifically in primary education.

The question of French minorities was repeatedly raised throughout the interactive dialogue of the first cycle of the UPR (2008-2011) of France [8]. The UN Member States felt concern about the French concept of minority rights and the related practice. In the course of the review various recommendations touching upon the minority issues were given to France. But the State abode by its traditional position in respect of minorities and partially accepted only those recommendations, the implementation of which was possible without revision or rejection of its concept of minority rights. As for the question of linguistic minorities of France, it wasn't separately raised by the participants of the interactive dialogue, but was it indirectly addressed by France itself when it mentioned that a draft bill on constitutional reform that also dealt with the status of regional languages was at that time under consideration and that it undertook to accede to the ECRML. Subsequently, on 23 July, 2008, France indeed adopted a constitutional amendment by virtue of which Article 751 stating that regional languages are part of the heritage of France was added to the text of the French Constitution. As for 
the ECRML, France hasn't yet ratified the Charter, which it has signed 17 years ago.

In the course of the interactive dialogue of the second cycle of the UPR of France the participants were still concerned about the situation in respect of French minorities noting an increase in discrimination and other forms of intolerance against minorities and calling for protecting the rights of children belonging to minorities [9]. This time the questions related to the vulnerable position of linguistic minorities weren't still raised as a separate matter of discussion, but it was indirectly touched upon by Slovenia, which expressed concern about the fact that a great number of French languages were severely endangered, and reflected in several specific recommendations. Further, France completely accepted about $80 \%$ of all the recommendations touching upon the minority issues, but in general it turned out that since the first cycle of the review France hadn't changed its position in respect of minorities and was still guided by its constitutional principles.

We also came up to the conclusion on the basis of our calculations of the relevant minority recommendations given to France within the framework of the first and second cycles of UPR that during the period from 2008 to 2013 the world community's concern about the problems of the protection of minorities in France had noticeably increased.

\section{CONCLUSION}

It seems important that France should one more time thoroughly consider the recommendations given by the human rights treaty bodies and the UN Special Rapporteur on minority issues and those ones given to France by the UN Member States in course of the UPR since their implementation can significantly improve the situation of the French linguistic minorities as well as contribute to the preservation of their cultural and linguistic identity.

\section{REFERENCES}

[1] Sastry T. S. N. Human rights of vulnerable and disadvantaged groups Course book - II. 1st ed. Pune: Registrar, University of Pune, 2012. P. 25.

[2] Petričušić A. The Rights of Minorities in International Law: Tracing Developments in Normative Arrangements of International Organizations // Croatian International Relations Review, Vol. XI No.38/39, 2005. URL: https://bib.irb.hr/datoteka/421246.CIRR_Petricusic_MR_IL.pdf.

[3] Abashidze A.Kh. Zashchita prav menshinstv po mezhdunarodnomu i vnutrigosudarstvennomu pravu. M.: Prava cheloveka. 1996. (Abashidze A.Kh. Protection of minorities under international and national law. M. Human rights. 1996).

[4] European Court of Human Rights, Baylac-Ferrer and Suarez v. France (dec.) (no. 27977/04), 25 September 2008.

[5] UN human rights treaty bodies: law and legitimacy / ed. by H. Keller, G. Ulfstein. Cambridge: Cambridge University Press, 2012.

[6] Concluding observations on the fifth periodic report of France. 17 August 2015 // UN Doc. CCPR/C/FRA/CO/5; Consideration of reports submitted by States parties under articles 16 and 17 of the International Covenant on Economic, Social and Cultural Rights: Fourth periodic reports of States parties due in 2011: France. 20 March 2014. E/C.12/FRA/4.; Committee on the Rights of the Child: Concluding observations on the fifth periodic report of France. 23 February 2016. $\mathrm{CRC} / \mathrm{C} / \mathrm{FRA} / \mathrm{CO} / 5$.

[7] Report of the independent expert on minority issues. Mission to France. 19-28 September 2007 // UN Doc. A/HRC/7/23.

[8] Report of the Working Group on the Universal Periodic Review: France // UN Doc. A/HRC/8/47.

[9] Report of the Working Group on the Universal Periodic Review France. A/HRC/23/3. 